\title{
INFLUENCE OF HAY QUALITY ON RUMINAL FERMENTATION OF DAIRY COWS ESTIMATED THROUGH GAS PRODUCTION
}

\author{
Valbona Kolaneci \\ Agricultural University of Tirana, Faculty of Agriculture and Environment, \\ Department of Animal Production. Kamëz, Tirana, Albania \\ valbona_kolaneci@yahoo.com
}

\begin{abstract}
Increased production of high yielding dairy cows requires high levels of feed intake and diets rich in energy and nutrients. High concentrate and low structural fibre proportion in the ration influence digestive processes and can lead to ruminal and metabolic disorders. Since food digestion begins in forestomach, ruminal environment is a decisive factor that has a pronounced effect on the extent of nutrients break down and utilization. The aim of the study is to estimate the effect of hay quality on ruminal fermentation of dairy cows through gas production. Lactating fistulated cows were taken as digesta donor animals. The diets were formulated by combining concentrate with two hay qualities (good and moderate, depended on NDF content). Digesta samples were taken one hour before and 2.5 hours after feeding. The samples were incubated without and with hay, concentrate and cellulose standards in the Gas Test Incubator and the gas volume were read at different hours after incubation. Hay quality showed a strong effect on the gas production. Gas production from blank samples one hour before feeding, by a moderate hay quality was significantly higher than by good hay quality, which indicates better fermentation conditions in rumen by feeding fibre rich hay. The influence of hay quality on the digestion of substrates is statistically proved. By feeding rich fibre hay the substrate was better digested, especially hay standard.
\end{abstract}

Key words: dairy cows; ruminal fermentation; Gas Test

\section{ВЛИЈАНИЕ НА КВАЛИТЕТОТ НА СЕНОТО ВРЗ РУМИНАЛНАТА ФЕРМЕНТАЦИЈА КАЈ МЛЕЧНИТЕ КРАВИ ОДРЕДЕНО ПРЕКУ ПРОДУКЦИЈАТА НА ГАС}

Зголемувањето на продукцијата на високи приноси кај млечните крави бара високо ниво на земање храна и диети богати со енергија и нутритиенти. Високата концентрација и ниската застапеност на структурни влакна имаат влијание врз процесите на варењето и можат да доведуваат до руминални и метаболички нарушувања. Бидејќи варењето на храната започнува во руменот, руминалната средина е решавачки фактор со изразен ефект врз степенот на разградувањето на нутритиентите и нивното искористување. Целта на ова истражување беше да се процени ефектот на квалитетот на сеното врз руминалната ферментација на млечните крави преку продукцијата на гас. Како животни донатори беа земени млечните крави. Диетите беа изведени со комбинирање на концентратите со два квалитета сено (добар и среден, зависно од содржината на NDF). Примероци од дигестивната содржина беа земени еден час пред и 2,5 часа по хранењето. Примероците беа инкубирани без сено и со сено, концентрацијата и целулозните стандарди во инкубатор за тестирање гас и волуменот на гасот беа прочитани во утврдено време по инкубацијата. Квалитетот на сеното покажа значаен ефект врз продукцијата на гас. Гасната продукција кај слепите проби еден час пред хранењето со сено со среден квалитет беше сигнификантно повисока во споредба со сеното со добар квалитет, што покажува на подобри ферментациони услови во руменот при хранењето со сено богато со целулозни влакна. Влијанието на квалитетот на сеното врз варењето е статистички докажано. Крмата од сено богато со влакна како супстрат беше подобро варена.

Клучни зборови: млечни крави; руминална ферментација, гас-тест

\section{INTRODUCTION}

Fibre rich forage is an important feed source for ruminants. The supply of energy and nutrients requirements from feeds rich in CWC is enabled through holding a very complex digestive apparatus. As a consequence of the large volume and microbial population, in the digestive apparatus 
the CWCs are digested and utilized mainly for energy production. The fiber content of diets for lactating dairy cows is an important determinant of ruminal environment (Van Soest et al., 1991). The NRC recommends that the diets contain a minimum fiber percentage, depending on the stage of lactation and yield, but several factors other than fiber content of the diet, including the source of fibre (Hoover, 1986; Van Soest et al., 1991) influence the digestive response.

The different fibre content in hay affected clearly ruminal digesta characteristics and ruminal fermentation. These effects are closely related to the chemical composition and the degradation rate of both hay and concentrate (Tafaj et a., 2004). The significant effects of the interactions between the fibre content in the hay and the concentrate level on digesta composition, particle size and density are closely related to their influences on the rumen conditions, which are characterized through the results of ruminal fermentation $(\mathrm{pH}$, SCFA and bicarbonate concentration) (Tafaj et al., 2004).

The diets rich in hay with high fibre content influence the formation of the thick and dense particle layer in the rumen below the gas space and a relatively thin layer of liquid, where the fine particles are found (Van Soest, 1982). The effect of the particle layer on ruminal microbial fermentation is evident. This effect is associated with the attachment of microbes to the particles of this layer and the break down of the nutrients. In the end, the effect of the particle layer in microbial fermentation is attributed to the digestibility and digestion rate of nutrients, as well as the growth and hydrolytic activity of ruminal microorganisms.

This experiment was conducted to evaluate the effect of the hay quality on ruminal fermentation of dairy cows. Ruminal fermentation is evaluated through in vitro gas production of digesta probes. Gas production is considered as an indicator for the ability of the rumen content to digest concentrate, hay and cellulose substrates standardized for the Hohenheim Gas Test Method (Menke and Steingass, 1988).

\section{MATERIALS AND METHODS}

The experiment was carried out at the Institute of Animal Nutrition, University of Hohenheim, Germany. Two adult lactating Frisian cows
$(\mathrm{BW}=500-550 \mathrm{~kg})$, at the end of the lactation, each fitted with fistula $(\varnothing=100 \mathrm{~mm})$, were taken as donor animals. For the study of the effect of the hay quality on the rumen fermentation, a two factorial trial was used. The four diets were formulated by combining two factors, each with two levels. Two hay qualities good and moderate, respectively with $47.1 \%$ and $61.9 \%$ NDF in the DM, were combined in the diets with two levels of concentrates $(20 \%$ and $50 \%$ of the ration DM). The intake level and the diet composition for the four treatments is shown in Table 1.

Table 1

Intake level and diet composition for the four treatments

\begin{tabular}{lcccc}
\hline \hline & $\mathrm{C}^{1}$ & \multicolumn{2}{c}{$20 \%$} & \multicolumn{2}{c}{$50 \%$} \\
& $\mathrm{H}^{2}$ Moderate & Good & Moderate & Good \\
\hline $\begin{array}{l}\text { Intake level (kg DM/d) } \\
\text { Hay (kg DM) }\end{array}$ & 13,6 & 14,1 & 11,6 & 11,6 \\
$\quad$ moderate & & & & \\
$\quad$ good & & & 9,9 & \\
Concentrate mixures & 6.7 & 6.7 & 2.6 & 2.4 \\
(kg DM) & & & & \\
$\quad$ composition: & & & & \\
$\quad$ 53,8\% barley & 3.6 & 3.6 & 1.4 & 1.3 \\
$\quad$ 28,2\% wheat & 1.9 & 1.9 & 0.8 & 0.7 \\
$\quad$ 14,6\% soja oilcake & 1.0 & 1.0 & 0.4 & 0.4 \\
$\quad$ 1,1\% vegetarian oil & 0.07 & 0.07 & 0.03 & 0.03 \\
$\quad \begin{array}{l}\text { 2,3\% mineral } \\
\text { supplement }\end{array}$ & 0.15 & 0.15 & 0.18 & 0.17 \\
Forage / Concen. (\%) & $51: 49$ & $52: 48$ & $78: 22$ & $79: 21$ \\
ENL (MJ/kg LTh) & 6.21 & 6.63 & 5.07 & 6.12 \\
CP (\% LTh) & 12.8 & 13.7 & 11.4 & 12.7 \\
CF (\% LTh) & 19.8 & 16.6 & 26.7 & 20.7 \\
NDF (\% LTh) & 44.5 & 37.3 & 53.0 & 42.2 \\
\hline \hline
\end{tabular}

${ }^{1}$ Concentrate level; ${ }^{2}$ Hay quality

Feed availability was restricted (about 85 $90 \%$ of ad libitum intake) at the level of $13-14$ $\mathrm{kg} \mathrm{DM} / \mathrm{d}$. The animals were fed twice a day at 08:00 and 20:00 and had free access to water. The sampling technique was developed by Tafaj et al. (2001). 200 - $300 \mathrm{~g}$ digesta/animal were taken about one hour before and 2.5 hours after morning feeding in two days, between them was at least one 
"rest day", where no sampling took place. Digesta samples were incubated without and with hay, concentrate and celullose standards in the Gas Test Incubator. The gas volume was read off $0,3,6,9$, $12,24,36$ and 48 hours after the beginning of the incubation. Analyses of variance for the effect of hay quality, time and day of sampling and for interactions were carried out through the GLM Procedure (SAS/STAT, 1987). LSM were calculated and the influence of the factor hay quality was proved through the SS Type III and F-Value.

\section{RESULTS AND DISCUSSION}

The influence of the factor "sampling time" was highly significant. The influence of the main factor "hay quality" was stronger before than after morning feeding, as a result of the more constant composition and activity of the ruminal digesta before feeding. Consequently, daily variation of the gas production was more present after than before feeding, which supports the findings of Menke and Steingass (1988) and Cone et al. (1989), who came to the result that sampling time and diet composition have impact on in vitro technique.

Gas productions of blank samples were higher after feeding than before it during all the incubation period. That could be explained with the high concentration of easy degradable nutrients in digesta after feeding, which comes from the concentrate. The difference of the gas production is not dedicated to fibre contents in the digesta, as the measures done in the framework of the same project showed that the proportion of particles in digesta is lower after than before feeding (Tafaj et al., 2004).

The effect of the dietary factor "hay quality" on in vitro gas production will be discussed based on the Least Square Means ( $\mathrm{ml}$ gas) comparison for both levels of the factor. The gas production values from blank samples, where only digesta was incubated, and from digesta samples incubated with gas test standards to evaluate its ability to digest hay, concentrate and cellulose are presented in the Tables 2-5.

The comparison of the gas volume produced by digesta samples taken 1 hour before feeding shows that ruminal fermentation activity during all incubation times of the animals feed with moder- ate hay is significantly higher than that of animals feed good quality hay. No effect of hay quality on gas production from digesta samples taken 2.5 hours after feeding was shown (Table 2). The differences on the gas production as a result of different hay qualities of diets were more evident in the blank values, where no substrate was incubated with digesta. In blank values the observed effects are the consequence of inocula characteristics, respectively of the diet. This fact indicates the role of the fiber content and its nature on rumen stratification and intensity of fermentation.

The digesta effect taken from cows feed different hay qualities on in vitro fermentation of standard substrates is different (Tables 3, 4, 5). The fermentation rate of standard hay in in vitro cultures is higher when incubated with digesta taken from animals feed moderate hay quality (NDF content $61.9 \%$ of DM) (Table 3). Low fermentation rate of standard hay incubated with digesta taken from animals feed low fibre hay $(47.1 \%$ of DM) may result from the faster drop of digesta $\mathrm{pH}$ as a consequence of higher NFC content $(29.2 \%$ vs. $14.9 \%$ of $\mathrm{DM})$ and the higher fermentation rate $(7.0 \%$ vs. $5.7 \% / \mathrm{h})$. Low $\mathrm{pH}$ value leads to an inhibit cellulotic activity and a slowly break down of hay (Mould et al., 1984; Strobel and Russel, 1986; Shiver et al., 1986).

The effect of the quality of dietary hay on fermentability of standard cellulose incubated with digesta of animals feed hay with different NDF content is less pronounced. The differences are statistically proved only for three different incubation times (Table 5).

In general, the effect of fibre content of dietary hay on the fermentation level of standard concentrate incubated with digesta is significant (Table 4). After 12 hours of incubation the level of in vitro fermentation of concentrate incubated with digesta taken from animals feed hay rich in fibres is higher than the fermentation level of concentrate incubated with digesta from animals fed with poor fibre hay. In the first hours of incubation, the gas volume is higher in samples of concentrate incubated with digesta of cows fed with good quality hay. This shows a more intensive fermentation of digesta components of animals feed good quality hay. The gas produced at the beginning of incubation is product of nutrients fermentation of inocula. 
Table 2

Influence of hay quality $(H)$ on gas production $(L S M, m l)$ from digesta samples taken 1 hour before and 2.5 hours after the morning feeding

\begin{tabular}{|c|c|c|c|c|c|c|}
\hline \multirow{3}{*}{$\begin{array}{l}\text { Incubation } \\
\text { time (h) }\end{array}$} & \multicolumn{3}{|c|}{$1 \mathrm{~h}$ before feeding } & \multicolumn{3}{|c|}{$2.5 \mathrm{~h}$ after feeding } \\
\hline & \multirow{2}{*}{$\begin{array}{c}\mathrm{Nr}^{1}{ }^{1} \\
\text { observations }\end{array}$} & \multicolumn{2}{|c|}{ Hay quality $(\mathrm{H})$} & \multirow{2}{*}{$\begin{array}{c}\text { Nr. } \\
\text { observations }\end{array}$} & \multicolumn{2}{|c|}{ Hay quality (H) } \\
\hline & & Good & Moderate & & Good & Moderate \\
\hline 3 & 108 & $3.4^{\mathrm{b}}$ & $4.6^{\mathrm{a}}$ & 112 & $11.4^{\mathrm{a}}$ & $9.4^{\mathrm{b}}$ \\
\hline 6 & 108 & $6.6^{\mathrm{b}}$ & $7.7^{\mathrm{a}}$ & 112 & $19.6^{\mathrm{a}}$ & $18.0^{\mathrm{a}}$ \\
\hline 9 & 107 & $10.3^{\mathrm{b}}$ & $11.4^{\mathrm{a}}$ & 112 & $25.4^{\mathrm{a}}$ & $24.6^{\mathrm{a}}$ \\
\hline 12 & 107 & $13.9^{\mathrm{b}}$ & $15.2^{\mathrm{a}}$ & 112 & $29.8^{\mathrm{a}}$ & $29.7^{\mathrm{a}}$ \\
\hline 24 & 106 & $24.5^{\mathrm{b}}$ & $26.8^{\mathrm{a}}$ & 109 & $42.5^{\mathrm{a}}$ & $43.4^{\mathrm{a}}$ \\
\hline 36 & 105 & $32.2^{\mathrm{b}}$ & $35.2^{\mathrm{a}}$ & 107 & $51.3^{\mathrm{a}}$ & $52.2^{\mathrm{a}}$ \\
\hline 48 & 101 & $38.0^{\mathrm{b}}$ & $40.8^{\mathrm{a}}$ & 107 & $56.8^{\mathrm{a}}$ & $58.1^{\mathrm{a}}$ \\
\hline
\end{tabular}

${ }^{1}$ Number of observations in data set includes all readings of the runs and replicates in three rumen positions $(8$ runs $\times 4-5$ replicates $x 3$ rumen positions) before and after feeding.

${ }^{2}$ Different letters in row indicate significant differences $(\mathrm{P}<0.05)$ between levels within the factor.

Table 3

Influence of hay quality $(H)$ on gas production ((LSM, $\mathrm{ml} / 200 \mathrm{mg} D M)$ from standard hay samples incubated with digesta taken 1 hour before and 2.5 hours after the morning feeding

\begin{tabular}{|c|c|c|c|c|c|c|}
\hline \multirow{3}{*}{$\begin{array}{l}\text { Incubation } \\
\text { time }(\mathrm{h})\end{array}$} & \multicolumn{3}{|c|}{$1 \mathrm{~h}$ before feeding } & \multicolumn{3}{|c|}{$2.5 \mathrm{~h}$ after feeding } \\
\hline & \multirow{2}{*}{$\begin{array}{c}\text { Nr. } \\
\text { observations }\end{array}$} & \multicolumn{2}{|c|}{ Hay quality (H) } & \multirow{2}{*}{$\begin{array}{c}\mathrm{Nr} . \\
\text { observations }\end{array}$} & \multicolumn{2}{|c|}{ Hay quality (H) } \\
\hline & & Good & Moderate & & Good & Moderate \\
\hline 3 & 110 & $10.9^{\mathrm{a}}$ & $10.7^{\mathrm{a}}$ & 107 & $11.9^{\mathrm{a}}$ & $11.7^{\mathrm{a}}$ \\
\hline 6 & 110 & $19.0^{\mathrm{b}}$ & $20.0^{\mathrm{a}}$ & 107 & $20.9^{\mathrm{b}}$ & $22.6^{\mathrm{a}}$ \\
\hline 9 & 110 & $25.8^{\mathrm{b}}$ & $27.8^{\mathrm{a}}$ & 107 & $26.7^{\mathrm{b}}$ & $29.8^{\mathrm{a}}$ \\
\hline 12 & 110 & $31.0^{\mathrm{b}}$ & $33.0^{\mathrm{a}}$ & 106 & $31.6^{\mathrm{b}}$ & $34.4^{\mathrm{a}}$ \\
\hline 24 & 109 & $41.3^{b}$ & $43.7^{\mathrm{a}}$ & 105 & $40.9^{b}$ & $43.5^{\mathrm{a}}$ \\
\hline 36 & 107 & $45.3^{\mathrm{b}}$ & $48.9^{\mathrm{a}}$ & 104 & $45.0^{\mathrm{b}}$ & $47.0^{\mathrm{a}}$ \\
\hline 48 & 103 & $48.4^{\mathrm{b}}$ & $51.5^{\mathrm{a}}$ & 104 & $47.3^{b}$ & $49.0^{\mathrm{a}}$ \\
\hline
\end{tabular}

${ }^{1}$ Number of observations in data set includes all readings of the runs and replicates in three rumen positions $(8$ runs $\times 4-5$ replicates $x 3$ rumen positions) before and after feeding.

${ }^{2}$ Different letters in row indicate significant differences $(\mathrm{P}<0.05)$ between levels within the factor.

Table 4

Influence of hay quality $(\mathrm{H})$ on gas production ((LSM, $\mathrm{ml} / 200 \mathrm{mg} D M)$ from standard concentrates samples incubated with digesta taken 1 hour before and 2.5 hours after the morning feeding

\begin{tabular}{|c|c|c|c|c|c|c|}
\hline \multirow{3}{*}{$\begin{array}{l}\text { Incubation } \\
\text { time }(\mathrm{h})\end{array}$} & \multicolumn{3}{|c|}{$1 \mathrm{~h}$ before feeding } & \multicolumn{3}{|c|}{$2.5 \mathrm{~h}$ after feeding } \\
\hline & \multirow{2}{*}{$\begin{array}{c}\mathrm{Nr}^{1} \\
\text { observations }\end{array}$} & \multicolumn{2}{|c|}{ Hay Quality (H) } & \multirow{2}{*}{$\begin{array}{c}\mathrm{Nr} . \\
\text { observations }\end{array}$} & \multicolumn{2}{|c|}{ Hay Quality (H) } \\
\hline & & Good & Moderate & & Good & Moderate \\
\hline 3 & 93 & $21.5^{\mathrm{a}}$ & $18.6^{\mathrm{b}}$ & 87 & $22.2^{\mathrm{a}}$ & $18.5^{\mathrm{b}}$ \\
\hline 6 & 93 & $35.9^{\mathrm{a}}$ & $32.4^{\mathrm{b}}$ & 87 & $37.7^{\mathrm{a}}$ & $36.3^{b}$ \\
\hline 9 & 93 & $45.4^{\mathrm{a}}$ & $44.1^{b}$ & 87 & $45.3^{\mathrm{a}}$ & $46.7^{\mathrm{a}}$ \\
\hline 12 & 92 & $51.1^{\mathrm{a}}$ & $51.7^{\mathrm{a}}$ & 86 & $50.1^{b}$ & $52.3^{\mathrm{a}}$ \\
\hline 24 & 91 & $61.3^{\mathrm{a}}$ & $62.8^{\mathrm{a}}$ & 84 & $59.2^{\mathrm{a}}$ & $61.0^{\mathrm{a}}$ \\
\hline 36 & 89 & $65.1^{\mathrm{b}}$ & $67.0^{\mathrm{a}}$ & 84 & $62.2^{\mathrm{a}}$ & $63.8^{\mathrm{a}}$ \\
\hline 48 & 87 & $67.5^{\mathrm{a}}$ & $68.5^{\mathrm{a}}$ & 82 & $63.4^{\mathrm{a}}$ & $65.1^{\mathrm{a}}$ \\
\hline
\end{tabular}

${ }^{1}$ Number of observations in data set includes all readings of the runs and replicates in three rumen positions $(8$ runs $\times 4-5$ replicates $\times 3$ rumen positions) before and after feeding.

${ }^{2}$ Different letters in row indicate significant differences $(\mathrm{P}<0.05)$ between levels within the factor. 
Table 5

Influence of hay quality $(H)$ on gas production ((LSM, $\mathrm{ml} / 200 \mathrm{mg} D M)$ from standard cellulose samples incubated with digesta taken 1 hour before and 2.5 hours after the morning feeding

\begin{tabular}{|c|c|c|c|c|c|c|}
\hline \multirow{3}{*}{$\begin{array}{l}\text { Incubation } \\
\text { time }(\mathrm{h})\end{array}$} & \multicolumn{3}{|c|}{$1 \mathrm{~h}$ before feeding } & \multicolumn{3}{|c|}{$2.5 \mathrm{~h}$ after feeding } \\
\hline & \multirow{2}{*}{$\begin{array}{c}\text { Nr. }^{1} \\
\text { observations }\end{array}$} & \multicolumn{2}{|c|}{ Hay quality $(\mathrm{H})$} & \multirow{2}{*}{$\begin{array}{c}\text { Nr. } \\
\text { observations }\end{array}$} & \multicolumn{2}{|c|}{ Hay quality $(\mathrm{H})$} \\
\hline & & Good & Moderate & & Good & Moderate \\
\hline 3 & 111 & $1.0^{\mathrm{a}}$ & $1.2^{\mathrm{a}}$ & 114 & $1.6^{\mathrm{a}}$ & $1.5^{\mathrm{a}}$ \\
\hline 6 & 111 & $4.2^{\mathrm{b}}$ & $6.0^{\mathrm{a}}$ & 114 & $6.7^{\mathrm{a}}$ & $7.5^{\mathrm{a}}$ \\
\hline 9 & 110 & $13.9^{\mathrm{b}}$ & $17.7^{\mathrm{a}}$ & 114 & $18.2^{\mathrm{b}}$ & $22.7^{\mathrm{a}}$ \\
\hline 12 & 110 & $29.3^{\mathrm{b}}$ & $33.6^{\mathrm{a}}$ & 114 & $35.2^{\mathrm{b}}$ & $40.1^{\mathrm{a}}$ \\
\hline 24 & 107 & $71.4^{\mathrm{a}}$ & $72.9^{\mathrm{a}}$ & 110 & $74.3^{\mathrm{a}}$ & $73.0^{\mathrm{a}}$ \\
\hline 36 & 107 & $84.0^{\mathrm{a}}$ & $85.4^{\mathrm{a}}$ & 109 & $83.8^{\mathrm{a}}$ & $81.1^{\mathrm{b}}$ \\
\hline 48 & 106 & $87.4^{\mathrm{a}}$ & $88.1^{\mathrm{a}}$ & 108 & $86.1^{\mathrm{a}}$ & $82.2^{\mathrm{a}}$ \\
\hline
\end{tabular}

${ }^{1}$ Number of observations in data set includes all readings of the runs and replicates in three rumen positions $(8$ runs $\times 4-5$ replicates $\times 3$ rumen positions) before and after feeding.

${ }^{2}$ Different letters in row indicate significant differences $(\mathrm{P}<0.05)$ between levels within the factor.

\section{CONCLUSIONS}

Feeding factors showed a strong effect on the gas production. Gas production from blank samples one hour before feeding, by a moderate hay quality was significantly higher than by good hay quality, which indicates a better digesta stratification and fermentation conditions in rumen by feeding fibre rich hay. The influence of hay quality on the digestion of substrates is statistically proved. By feeding rich fibre hay the substrate was better digested, especially hay standard.

\section{REFERENCES}

[1] Cone W. J., Cline'-Theil W., Malestein A., Van'Tklooster A. T. (1989): Degradation of starch by inoculum with rumen fluid. A comparison of different starch sources. $J$. Sci. Agric. 49, 173-183.

[2] Hoover W. H. (1986): Chemical factors involved in ruminal digestion. J. Dairy Sci., 69, 2755 - 2766.

[3] Menke, K. H and Steingaß, H. (1988): Estimation of the energetic feed value obtained from chemical analyses and in vitro gas production using rumen fluid. Anim. Res. Dev., 28: $7-55$.
[4] Mould F. L., Ørskov E. R., Mann S. O. (1984): Associative effects of mixed feeds. Effects of type and level of supplementation and the influence of the rumen fluid $\mathrm{pH}$ on cellulolse in vivo and dry matter digestion of various roughages. Anim. Feed Sci. Technol., 10, 15 - 30.

[5] Shiver B. J., Hoover W. H., Sargent J. P., Crawford J. R. R. J., Thayne W. V. (1986): Fermentation of a high concentrate diet as effected by ruminal $\mathrm{pH}$ and digesta flow. J. Diary Sci., 69, 413.

[6] Strobel H. J. \& Russel J. B. (1986): Effect of pH and energy spilling on bacterial protein synthesis by carbohydrate-limited cultures of mixed rumen bacteria. J. Diary Sci., 69, 2941.

[7] Tafaj M., Junck B., Maulbetsch A., Steingaß H., Drochner W. (2001) Research Note: A method for studying of local differences in ruminal fermentation in diary cattle. Arch. Anim. Nutr., 54, 341.

[8] Tafaj M., Junck B., Maulbetsch A., Steingaß H., Piepho H.-P., Drochner W. (2004): Digesta characteristic of dorsal, middle and ventral rumen of cows fed with different hay qualities and concentrate levels. 1. Digesta composition, particle size and density and fermentation in the rumen. Arch. Anim. Nutr., 58, 325 - 342.

[9] Van Soest, P. J., Robertson, J. B., Lewis, B. A. (1991): Methods for dietary fiber, neutral detergent fiber and nonstarch polysacharides in relation to animal nutrition. J. Dairy Sci., 74, 3583. 